\title{
Role of Religion in Environmental Sustainability: An Indian Perspective
}

\section{Rola religii w kształtowaniu zrównoważoności środowiskowej: perspektywa Indyjska}

\author{
Sarita Kar ${ }^{\star}$, Manisha Tripathy ${ }^{\star \star}$ \\ Indian Institute of Technology (ISM), \\ Department of Humanities and Social Sciences, Dhanbad-826004, India \\ E-mails:*karsarita@gmail.com,**manishatripathy403@gmail.com,
}

\begin{abstract}
Environmental trepidations are global issues, environment sustainability is conceivable with the noble motive, which takes real shapes with the insights and perspectives from different religions. In the process of learning and teaching laid down by religion help to expand our understanding and develop our behavior towards nature. Role of religion to shape our attitudes to the natural world is significant, because its domination in human personality is always recognizable.

The paper would like to find out different prospect to achieve environment sustainability with the help of imperatives given by Indian religion. This imparts many valuable imperatives which unify nature as an inseparable part of human life and vice versa. Three major religions originating from India were explored in this paper: Hinduism, Buddhism and Jainism. The paper tries to show the human affiliation with nature is well expressed in every aspect of Indian religious life.
\end{abstract}

Key words: Nature, Religion, Hinduism, Jainism, Buddhism

\section{Streszczenie}

Gdy degradacja środowiska stała się problemem globalnym, zrównoważony rozwój środowiska można sobie wyobrazić dzięki szlachetnemu motywowi, który przybiera realne kształty dzięki wglądom i perspektywom z różnych religii. $\mathrm{W}$ procesie uczenia się i nauczania nakreślonego przez religię pomagamy poszerzyć nasze rozumienie i rozwijać nasze zachowanie wobec natury. Rola religii w kształtowaniu naszego stosunku do świata przyrody jest znacząca, ponieważ jej dominacja w osobowości człowieka jest zawsze rozpoznawalna.

Artykuł podejmuje próbę rozpoznania perspektywy osiągnięcia zrównoważenia środowiska za pomocą imperatywów podanych przez religię indyjską. Daje to wiele cennych imperatywów, które jednoczą przyrodę jako nieodłączną część ludzkiego życia i vice versa. W artykule tym omówiono trzy główne religie wywodzące się z Indii: hinduizm, buddyzm i dżinizm. Artykuł stara się pokazać, że związek człowieka z naturą jest dobrze wyrażony w każdym aspekcie indyjskiego życia religijnego.

Slowa kluczowe: natura, religia, hinduizm, dżinizm, buddyzm

\section{Introduction}

The Indian religious tradition are entangled with various cultural, social, philosophical as well as ethical values which has developed with history of many years, which embraces multiple movements, external interventions, and internal revolutions. The philosophical traditions of India are rich and numerous, offer many theoretical and practical perspectives on the human living and imparts many value laden imperatives to improve human conditions, and its environment. The philosophical ideas and ethical teachings have a significant impact not only within Indian scenario but it can help the conditions and problems of all parts of the globe. This paper is trying to trace certain significant points as well as imperatives 
given by different religious directives of India towards nature. This paper revitalize those thoughts to get a new outlook for solving any practical problems faced by our environment.

Human Civilization is currently facing many ecological complications, i.e. climate change, natural disasters, pollution, and related health issues (IPCC, 2007; IEEP, 2006; ILO, 2018; The Lancet Commissions, 2009). All the above concerns are connected to nature's ability to sustain life. Even human society stand with glitches to endure themselves with a limited resources available in the globe. The ability to maintain and sustain in this scenario is called sustainability. The challenges of sustainability can be imagined with the allegory of shrinking capacity of Earth: although environmental burdens are intensifying, available extent of natural resources are dwindling. Precaution must be taken from all perspective. Specific complication as opposed to looking at the challenge from a global perspective is not splendid (Karl-Henrik, 2000).

When thinking of making a real effort towards sustainability, it must be recognized that development and technology made a significant impact (negative) on environment and its availability (IPCC, 2007). It demands a new geographical era named Anthropogenic (Zalasiewicz et al., 2008) or it can defined as a new human period. Other than the efforts made by governmental policies and regulations to control the impact of climate change, but research shows that the progress expected is very dawdling (Lenton, 2012; Cook, 2009). Literature guides a significant change in human behavior and attitude towards sustainability is vital.

\section{Role of Religion in stimulating pro-environmen- tal behavior}

From primitive mind to contemporary thought religion was of paramount significance. In order to recognize the human life style and thinking, one had to study their values that they had adopted from the religion they belonged. Since ages, it would have been difficult to find any human being who did not belong to any religion. As religion is a universal manifestation, it expresses with values and stands (Lowie, 1963). Although immense variations found in the outward observance, inner structure and the purpose of religion are identical. They are alike in their sense of inner conviction, strong faith and their dependence upon some force outside themselves. The primitive, religion might have made human life supersites, rigid in many way, but the values and ethical standards passed on to human life through religion, made human being conscious and virtuous. Religion made them men of faith and faith in goodness insight them to be good and virtuous. So, religion has an encouraging place in human life and in human society, understanding and consciousness towards the need of present.
This universal appeal of religion has almost vanished from contemporary life of different parts of the world, but Rober H. Lowie, mentioned during his field work he found it alive in India and it still influenced the virtues of life and people in India to solve contemporary problems (Lowie, 1963).

The charisma of religion in the human life has immense. A faith in religion give confidence to face crises. Ethics recognize its foundation in religion. It has a vital place in everything an individual does, from believe to judgment he possess, the vision he carry forward. Although religion is not only the sole source of integration but there are sources like art, culture, education, which influence human life. For most of the individuals, religion is still the most available source of amalgamation of views. This point not only justifies its presence but also explains its universal allure. Now it is the time to take a momentary look to the present situations that have deliberately set about eradicating religion and facing present disasters.

\section{Role of Religion in Environmental Sustainability}

Role of religions are vital in motivating the behavior of their admirers from the very beginning. It has a significant effect on their food habits, customs and the way they live their daily lives. Human civilization is constantly evolving with religion from the earliest days of their existence. Religion has not only changed the life of primitive human society but it has a vigorous impact on today's life and the behavior of human beings (Palmer and Finlay, 2003). The CIA's World Fact book consider that religions are the primary foundation to shape the daily living style of more than $75 \%$ world's population. (CIA World Fact Book, 2009). Literature shows religious imperatives have a larger impact on the human believe and its subsequent work. So Religion plays an authentic role at changing behaviors in light of the sustainability challenges (Hulme, 2009; Slimak \& Dietz, 2006).

Religion can act as dominant potency to change the human attitude towards more sustainable way of life. There are many example which indicates the inspiration of religion in bringing sustainability, i.e. $e x$ periment in Tanzania that is emerging as an Islamic model for spreading environmental ideals (Barclay, 2007). Even the United Religions Initiative (URI) is a global prevalent interfaith network that supports peace and justice through its interfaith network. URI also persuades the project of sustainability. It works with a mission and aim to create cultures of peace, justice and healing for the Earth and all living beings (URI, 1996).

A conclusion can be drawn from above evidences that religions have a remarkable influence on changing attitude towards sustainability (Palmer and Finlay, 2003). The gist of sustainability is present in all the religion of the world and in their supporting scriptures. Although the word sustainability was not 
explicitly used before but its essence was felt and advocated by all religion throughout history. Religious Association like ARC (Alliance for Religion and Conservation, UK) is focusing on the urgent requirement of approaches from each religion to preserve sustainability. Each major religion is trying to treasure their own religious imperatives to solve the sustainability challenges (ARC, 1995). Mary Evelyn Tucker recommends that religion will be a key adherent for the environmental emergency calls and the different religions of the world have to return to their ethical imperatives for sustaining environment as a voice of global community (Tucker, 2004).

\section{Religion to awaken Environmental Sustainabil- ity: An Indian Perspective}

The Indian religion is knotted with different cultural, social, philosophical systems that have recognized over a history, compounded with movement of peoples, foreign interventions, and internal transformations in structures and identities experienced over time. Three major religion originating from India are: Hinduism, Buddhism and Jainism. Mostly these three comprise the oldest religious traditions of the Indian subcontinent. Indian Religion and Philosophy has a remarkable work in this field, but it needs to rejuvenate those thoughts to get a solution to our environmental problems and finding a way to achieve environmental sustainability. The ethical teaching, principles found in Indian religion, are transferred from generation to generation and become a way of human life. Those eco-friendly ethical standards influenced human life and become a virtue of their life and subsequently gets passed on to different generation.

\section{Hinduism: Divinity in Nature}

The most fundamental philosophical tradition in India has tried to formulate the philosophical thoughts with three concepts of God, Nature and Man - the Supreme Being, the Universe, and the Individual Self. Indian Philosophy never tries to make any demarcation between these three concepts, in its philosophical sense it is very much interrelated. The Hindu concept of the natural world is the belief in the Ultimate Absolute Reality, the Supreme Self, which described as Existence-Consciousness-Bliss (Swami Ranganathananda, 1980). The Hindu scriptures identify God with the Universe, the natural world of multiplicity and differences; it widely accepted views among Hindu scriptures that Brahman transforms Himself into the ever blossoming and developing form of the external world. Even the individual souls of men are thought of as identical with highest soul. The Supreme Being is the whole universe, animate and inanimate. He is the origin of it, the place of its preservation and of its dissolution at the end of the long cycle of existence. Moreover, in the concept of Lila in Hindu Philosophy, the creative play of the Gods, described as the world as a creative manifestation of the divine (Tucker and Chapple, 2000). Therefore Hindus always see themselves in everything and everything in Him, and worship Him as abiding in all kinds of created things (McKenzie, 1971). This reflect the love and respect for all the creation of Hindus, they respect all the living beings of the universe, in the extreme they never tries to separate their life in any way from any inanimate creation, they conceptualize all the existence as manifestation of the same Supreme Being (Callcott,1987). Accepting the words of Bhagvad Gita, I stand pervading this whole universe with a single fragment of myself (Basak, 1953), almost all Hindus believe and acknowledge the immanence of Ultimate Reality in all objects of nature; they never fail to reflect on His transcendence of the created world. The Vedic traditions of Hinduism offer metaphors that value the power of the natural world. Scholars of the Vedas have held forth various texts and rituals that extol the earth (bhu), the atmosphere (bhuvah), and sky (sva), as well as the goddess associated with the earth (Prthivi), and the gods associated with water $(A p)$, with fire and heat (Agni), and the wind (Vayu). They have noted that the centrality of these gods and goddesses suggests an underlying ecological sensitivity within the Hindu tradition (McKenzie, 1971).

\section{Jainism: Liberation with Nature}

Jains of India have always been very much philanthropic to all types of lives; they have practically been talking about the modern topic ecology throughout the centuries. Lives of all types have always been very precious in their philosophy- na hanyet na ghatayet, it means one should not kill and should not cause to kill. This is the basic motto of their philosophy (Chapple, 2006).

It developed a path of renunciation and purification designed to liberate one from the shackles of karma, allowing one to enter into a state of eternal liberation from rebirth, or kevala. The primary method of attaining this ultimate state requires a careful observance of nonviolent behavior. Jainism emphasizes nonviolence, or Ahimsa, as the only true path that leads to liberation and prescribes following rigorous rules for the protection of life in all forms. Jainism has a system of ethics that places non-violence at the top of its principle of morality. Abstaining from any kind of injury, in thought, word, and deed, to any kind of living being, immobile or mobile is ahimsa (Jain, 2011).

The common concerns between Jainism and environmentalism can be found in a mutual sensitivity toward living things, recognition of the interconnectedness of life forms. For the Jains, this approach is anchored in a cosmology that views the world in terms of a cosmic woman whose body contains countless life souls (jiva) that reincarnate repeatedly until the rare attainment of spiritual liberation ( $k e v$ - 
ala). The primary means to attain freedom requires the active non-harming of living beings, which disperses the karmas that keep one bound. Jains adhere to the vows of non-violence to purify their karma and advance toward the higher states of spiritual attainment. For Jaina laypeople, this means the need to avoid doing harm to all forms of life, including bugs and microorganisms. Our ecosystem becomes impoverished, humans take notice and respond. Similarly, according to the Acaranga Sutra, Mahavir was moved when he observed nature at close range, noticing that even the simplest piece of a meadow teems with life (Chapple, 2002). The goal within Jainism is to ascend to the Siddha Loka, a world beyond heaven and earth, where all the liberated souls dwell eternally in a state of energy, consciousness, and bliss. Hence, from the aspect of practice, Jainism holds some interesting potential for ecological thinking, though its final goal transcends earthly concerns (Chapple, 2001).

You are the one whom you intended to kill, you are the one you intended to tyrannize, you are the one whom you intended to torment, and you are the one you intended to punish. The enlighten one who lives up to this dictum neither kills nor causes other to kill thus, Bondage and emancipation are within yourself (Tatia, 2006) Therefore, the worldview of the Jainas might be characterized as a bio-cosmology. Due to their perception of the livingness of the world, they hold an affinity for the ideals of the environmental movement (Holmes, 1987).

\section{Buddhism: Life with Nature is Sacred}

In Buddhist religion, nature was considered sacred. Nature had been very close to the Buddha in all the important occasions of his life, he was born in a garden, he attained Buddha-hood and passed away from this world under the trees, and he preached his first sermon in a deer park and from then on always he stayed outdoors in the shade of trees. (Ariyaratne, Macy, 1992). The word Dharma means religion in Buddhist philosophy. For Buddhist, it is the sacred law, morality and the teachings of the Buddha. It is also all things in nature. All creatures including inanimate creation are all dharma. So at its very essence, Buddhism can be described as an ecological religion or a religious ecology. Buddhist philosophy begins with the principles of love, compassion and respect for all life. The very heart of Buddhist thought it procures the ecological sensitivity. This thought expresses that our birth and existence is dependent on causes outside us, inextricably linking us with the world and denying us any autonomous existence. We and all nature are inseparable, entwined, all one.

Two of the most important qualities are developed by Buddhists are loving-kindness and compassion. Loving-kindness is understood as the wish for others to be happy, and compassion as the wish to alleviate suffering. Both starts with ourselves, by recognizing the fact of our own suffering and seeking to uproot its causes. Before turning to the plight of others, it is necessary to understand deeply the origins of suffering within ourselves. Such insight can then lead to a genuine capacity to show others the way to freedom from their inner pain. Ultimately loving-kindness and compassion extend to all living things: people, animals, plants, the earth itself. The root of compassion is wisdom. Wisdom is not an introverted intellectual quality but, Buddha explains it can only be give rise through a spontaneous concern for life. According to him, the four great elements of earth of earth, water, fire and air are the components of both our own and others' bodies. For these reasons, we should give life to others by setting them free (Batchelor, 1992). According to the Nobel Peace Prize Lecture of the Dalai Lama, we all share this small planet earth, so we should learn to live in harmony and peace with each other and nature. He explains staying together as family is not just an impressive idea, but a necessity. We are dependent on each other in so many ways that we can no longer live in isolated communities and ignore what is happening outside those communities (Burford, 1992; Gross, 1997). We need to help each other when we have difficulties, and we must share the good fortune that we enjoy (Dalai Lama, 1992).

\section{Conclusion}

The contemporary problems are due to our alienated form of life from religious influence in our life. When science started unveiling the secrets of nature one by one, humanity gradually lost faith in theistic religions. Consequently moral and spiritual values were also discarded. Since the Industrial Revolution and the consequent acquisition of wealth through technological exploitation of nature, humanity has become more and more materialistic. It promised us a comfortable life with moral deterioration, which is a double-edged weapon; it has adverse effects on humanity's mental and physical well-being as well as on nature. In the present eco-crisis humanity has to look for radical solutions and that can be determined only through our values, priorities and choices. The human beings should reappraise its value system. So all the religion teaches us that mind is the forerunner of all things. If we act with an impure mind, a mind with greed, hatred and delusion, suffering is the inevitable result. The action follows by pure mind, with the qualities like contentment, compassion and wisdom, happiness will follow like a shadow.

\section{References}

1. ARIYARANTE A.T, MACY J., 1992,The Island of Temple and Tank, Buddhism and Ecology, eds. Batchelor M., Brown K., Motilal Banarsidass Publishers, Delhi: 88-82. 
2. ARC,1995, http://www.arcworld.org/about_ARC.as $\mathrm{p},(06.02 .2020)$.

3. BARCLAY E., 2007, African Fishermen Find way of Conservation in the Koran, Cristian Science Monitor, October 31, https://www.csmonitor.com/2007, (18.01.2020).

4. BARNHART M.G., 1997, Ideas of Nature in an Asian Context, Philosophy of East and West, 47.

5. BASAK RADHAGOVINDA, 1953, The Hindu Concept of the Natural World, The Religion of the Hindus, ed. Morgan K. Motilal Banarsidass publishers, Delhi.

6. BATCHELOR M., 1992, Even the Stones Smile, Buddhism and Ecology, eds. Matchelor M., Brown K., Motilal Banarsidass Publishers, Delhi: 4-6.

7. BURFORD G., 1992, A Buddhist Response, Buddhist-Christian Studies, 12.

8. CALLCOTT J.B., 1987, Conceptual Resources for Environmental Ethics In Asian Traditions of Thought: A Propaedeutic, Philosophy of East and West, 37(2).

9. CIA (Central Intelligence Agency), 2009, CIA The World Fact Book, Potomac Books, Skyhorse Publishing.

10. CHAPPLE C.K. (ed,), 2001, The Living Cosmos of Jainism: A Traditional Science Grounded in Environmental Ethics, Religion and Ecology: Can the Climate Change? Daedalus, 130(4).

11. CHAPPLE C.K. (ed.), 2002, Religion of the World and Ecology, Religions of the World and Ecology Series, Harvard University Press.

12. CHAPPLE C.K. (ed.), 2006, Jainism \& Ecology, Motilal Banarsidas, Delhi.

13. COOK H.K., 2009, Abrupt Climate Change: Atmospheric Tipping Points, IOP Conference Series: Earth and Environment Science, 6(6).

14. GROSS R.M., 1997, Toward a Buddhist Environmental Ethic, Journal of the American Academy of Religion, 65(2).

15. HULME M., 2009, Why we disagree about climate change: Understanding controversy, in action and opportunity, Cambridge University Press, New York.

16. IPCC, 2007, AR4 Climate Change 2007: The Physical Science Basis, https://www.ipcc.ch/site/assets/uploads/2018/03/ar4_wg, (06.02.2020).

17. JAIN P., 2011, Dharma and Ecology of Hindu Communities: Sustenance and Sustainability, Ashgate Farhham Surrey, UK.
18. LAMA DALAI, 1992, A Zone of Peace, Buddhism and Ecology, eds. Batchelor M., Brown K., Motilal Banarsidass Publishers, Delhi: 110.

19. LENTON T., 2012, Arctic Climate Tipping Points, Ampio: A Journal of Human Environment, 41(1): 1012.

20. LOWIE R.H., 1963, Religion in Human Life, American Anthropologist, 65(3): 532-542.

21. MARTIN P., FINLAY V., 2003, Faith in Conservation: New Approaches to Religions and the Environment, World Bank Publication.

22. McKENZIE J., 1971, Hindu Ethics: An Historical and Critical Essay, Oxford University Press, London: 103-105.

23. PALMER M., FINLAY V., 2003, Faith in Conservation. New Approaches to Religions and the Environment, The World Bank, Washington D.C.

24. RANGANATHANANDA SWAMI, 1980, The Message of Upanishads: An Exposition of the Upanishads in the Light of Modern Thought and Modern Needs, Bombay, Bharatiya Vidya Bhavan: 482-493.

25. ROBERT K.H., 2000, Tools and Concepts for Sustainable Development, How They Relate to a General Framework For Sustainable Development and to Each Other?, Journal of Cleaner Production, $8(3)$.

26. ROLSTONE HOLMES Holmes III, 1987, Can the East Help the West to Value Nature?, Philosophy of East and West, 37(2).

27. SLIMAK M.W., DIETZ T., 2006, Personal values, beliefs, and ecological risk perception, Risk Analysis, 26(6): 1689-1705.

28. TUCKER M.E., 2004, Worldly Wonder: Religions Enter Their Ecological Phase, Open Court, Chicago.

29. TUCKER M.E., CHAPPLE C.K. 2000, Religion of the world and Ecology Book Series.

30. TATIA N., 2006, The Jain Worldview and Ecology, Jainism and Ecology: Nonviolence in the Web of Life, ed. Chapple C.K., Motilal Banarsidass Publishers, Delhi.

31. URI, United Religion Initiative, 1996, http://www. uri.org/, (15. 01.2020)

32. WEBER T., 1999, Gandhi, Deep Ecology, Peace Research and Buddhist Economics, Journal of Peace Research, 36(3).

33. ZALASIEWICZ J., WILIAMS M., SMITH A., Barry T.L., 2008, Are we Now Living in the Anthropogenic? GSA Today, 18(2): 4. 